\title{
Community Supporting Attitude toward Community-Based Tourism Development; Non-Participants Perspective
}

\author{
Sajad Ebrahimi ${ }^{1} \&$ Zainab Khalifah ${ }^{2}$ \\ ${ }^{1}$ Faculty of Built Environment, University Technology Malaysia, Malaysia \\ ${ }^{2}$ Faculty of Management, University Technology Malaysia, Malaysia \\ Correspondence: Zainab Khalifah, Faculty of Management, University Technology Malaysia, Malaysia. E-mail: \\ Zainab@fppsm.utm.my
}

Received: October 10, 2013 Accepted: March 11, 2014 Online Published: August 20, 2014

doi:10.5539/ass.v10n17p29 URL: http://dx.doi.org/10.5539/ass.v10n17p29

\begin{abstract}
Non-participants in a host community play a vital role in the success of that destination. Community participation issues in a destination may propel a community to fail in their relations, businesses and attachments. In addition, there is a bias toward participants rather than non-participants in previous studies and non-participants in tourism activities have been neglected, therefore this study aims to investigate the supporting behavior of those non-participants and tries to identify factors discourage local people to participate in Community-Based Tourism activities by using a qualitative local participation approach. The results indicate the existence of a wide range of factors including; relation with current participants; time and capital limitations; religious and cultural sensitivities; envious sensitivities and communication barriers effect local participation in community-based tourism and specifically Malaysia Homestay Program.
\end{abstract}

Keywords: community participation, community support, homestay program, non-participants, resident attitude

\section{Introduction}

Communities, especially in third world countries are unaware of the costs and difficulties associated with rapid development of tourism in their community (Alonso \& Liu, 2012; Jafari, 1981; Rosenow \& Pulsipher, 1979; Tosun, 2000). Although some authors such as Tosun (2000) proposed community attachment as panacea, there are still a number of people who are not joining tourism activities due to unknown reasons.

Local participation has been regarded as a precondition in the success of Community-Based Tourism (CBT) projects by many scholars (Inskeep, 1991; Simpson, 2008; Stone \& Stone, 2010; Shani \& Pizam, 2012). Also some considered the reality of social structures and community internal relations as essential factors in sustaining the CBT programs (Meimand, 2013; Mowforth, 2008; Simpson, 2008). However, the views of non-participants are equally important, since problems and conflicts arise may delay the pace of tourism development. For example in the case of Kaikoura Whale Watching in New Zealand, shortly after its establishment in 1990, non-participants burnt tourists' coach, vandalized the boats and burgled the administration office, due to mainly due to lack of understanding of the tourism business and economic jealousy (Gillespie, 2000). In addition local participation, community perceives, constructs and participations in developing countries have been attracting the attention of tourism academics in the last few years (Alonso \& Liu, 2012; Stone \& Stone, 2011; Tosun, 2000). Such phenomenon in tourism activities has been debated in the field of sociology and anthropology of tourism. Studies in this field lied on anthropological perspectives and assumed communities are not a homogeneous people either they support or do not support the tourism industry (Buono, Pediaditi, \& Carsjens, 2012; Kapoor, 2001; Kibicho, 2008). In the same vein, this study attempts to investigate related parameters to community support and participation in Community-Based Tourist destinations.

Therefore, it can be concluded that there is a bias toward participants rather than non-participants in previous studies and non-participants in tourism activities have been neglected in these studies, therefore this study aims to investigate the behavior of those non-participants.

\section{Local Participation}

Participation has been defined in a variety of ways by different scholars. Skeffington (1969) simply defined the public participation as "a sharing action to formulate policies and proposals" while in 1973 a more 
comprehensive definition provided for public participation, "the means by which people who are not elected or appointed, officials of agencies and of government influence decisions about programs and policies which affect their lives" (Brager et al., 1973). Based on this definition, tourism may act as the program or policy which can influence the host community lives. Moreover,Shirlow \& Murtagh (2004) in a more recent article described participation in which non-participants were clarified, "an umbrella body that covers various distinct stakeholders represented on the one hand by an organized sector that represents people with varied interests but share a common goal and, on the other, those with no interest at all in the shared common goal".

In addition, local Participation has been taken into attention from different perspectives; some scholars considered local participation as an effective factor in sustainable development (Gunn \& Var, 2002; Mair \& Reid, 2007; Mowforth, 2008); some believe on catalyzing effect of local participation by enhancing their economic benefits from tourism and investing in other sectors (Stronza \& Gordillo, 2008); Garrod (2003) discussed effective planning and management in the shadow of local participation; in a recent study, effective investment return has been proven in Vietnam through active local participation (Yen \& Van Luong, 2008) and finally, some emphasized importance of widespread tourism participation in planning process (Gunn \& Var, 2002; Inskeep, 1991).

Non-participants have been known as a challenge for tourism developers, planners and managers. A study in Vietnam showed that non-participants are potentially sensitive about tourism development and they believe that tourism is destroying their culture (Yahya, And, \& Sebastian, 2005). In this context, this study deals with investigation of non-participants supporting behavior toward participation in tourism activities to answer the question of "Why does a local who has the necessity and ability to join tourism activity, is not interested to join?"

As mentioned previously, there are a few models which tried to investigate factors influencing residents' supporting behavior. Gursoy et al. (2002) introduced a structural model which found out the correlations in influencing factors to community participation in tourism activities (Gursoy et al., 2002). The level of community concern of local residents; the utilization of the tourism resource base of local residents; the level of eccentric issues; the state of the local economy; the perceived cost; and the perceived benefits of the tourism development are the most effective factors in this study (see Gursoy et al., 2002). Although this study provided a structural model, some important factors disregarded; factors such as social concerns, occupancy, religious concerns and psychological sensitivities. Another study by Kayat (2002) attempted to investigate the factors influencing individual participation in Community - Based Tourism in the context of Malaysian Homestay. The article derived that local participation is affected by motivation factors including; the degree of control on decision making, needs for self-development, to play a role in community development, sense of belonging, gain self-respect or to gain self-fulfillment and income generating purposes. Although this research found out useful variables about local participation, it just focused on a limited number of attribute and also it emphasized on intangible attributes rather than tangible characters.

\section{Homestay Program Malaysia}

Homestay term has different usages and definitions in different countries. In United Kingdom Homestay is used for those who want scale up their English language proficiency through living with a native family while Australian use the term for farmhouse accommodation (Ibrahim \& Rashid, 2010). Malaysia Ministry of Tourism defined the Homestay program as "Where tourists stay with the host family and experience the everyday way of life of the family in both a direct and indirect manner" ( MOCAT, 1995, cited in Ibrahim \& Rashid, 2010).

Homestay program evolution in Malaysia returns back to the early 1970s, when an old lady provided meal and accommodation for visitors within her humble village house (Hamzah, 1997). The main purpose of this program is to accommodate visitors with a local family in a village atmosphere, therefore it provides a golden opportunity for visitors to experience pure local lifestyle and culture (Ebrahimi Meimand \& Ismail, 2011). Furthermore, among Malaysia's attractions, Homestay program form rural tourism pillars. The Malaysian government is using the Homestay program as a key tool for decentralization of tourism income (Bagul \& Bahar, 2009).

Banghuris Homestay is established in 1993 as a trial Homestay and became an official Homestay under the authority of Tourism Malaysia after two years. Banghuris manager started the program with 18 participants and the numbers of participants have been reached 80 respondents in the early 2012. Banghuris term is a combination of three other names; Bangkung, Ulu Chuchoh and Ulu Teris (BANG+HU+RIS). Banghuris is located in the vicinity of Kuala Lumpur International Airport (KLIA) and $80 \mathrm{KM}$ far from Kuala Lumpur in the west of Peninsular Malaysia. Figure 1 shows the location of Banghuris and details of three included villages. 


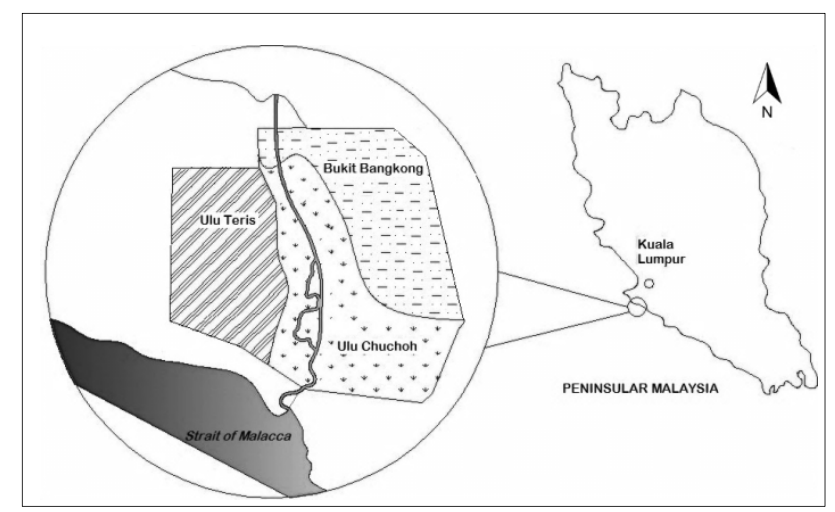

Figure 1. Banghuris location

\section{Research Methodology}

As the main aim of this study was to understand non-participants supporting behavior by studying the case of Malaysian Homestay, non-participants in Banghuris Homestay program studied. As noted earlier, exciting research on the community and local participation has been primarily undertaken by psychologists, sociologists and anthropologists who all have often been of a qualitative nature. In the same way, this study engaged qualitative approach by taking into consideration the advantages and disadvantages of qualitative and quantitative methods, in which a semi structured face-to-face interview was used. According to Bryman (2008), qualitative research allows the researcher to meet a better understanding of study population and their reality of life by involving and coping with them. In addition, it allows studying events during the study rather providing a statistical image of the study. It also provides the opportunity of finding the social relations (Flick, 2009). In the case of Homestay low literacy and lack of English proficiency restricted the researcher to do the questionnaire survey and the questions were needed to be asked in the form of semi-structured face to face interviews. Furthermore, in traditional Malaysian lifestyle and rural atmosphere personal conversation play a vital role to understand the reality of their life (Daldeniz \& Hampton, 2012). Also, the informal nature of qualitative studies and interviewing without a list of fix and pre-existing questions allow the respondents to provide a better image of their lifestyle. It is noticeable that interviews lasted on average, around one hour.

This then allows us to conduct interview sessions to the intended research area, including questions about economics, culture, social and religious issues. To ensure instrument validity, experts were asked to review if the semi-structure interview questions covered all aspects of study that they would expect. The questions in the semi structure interviews derived from previous literature cited in local participation section.

To enhance the generalizability of the study we used several participants from different areas, ages, carriers, genders and education level. In addition, interviewees consisted of three age categories, females and male, ranging in age from $20 \mathrm{~s}$ to mid-30s, mid-30 to 40s and 50s or more. Considering, 10 interviewees were selected from each village (Bukit Bankong, Ulu Chuchoh and Ulu Teris) as the study was held in all three villages (See Figure 1).

Interview sessions were recorded on a digital audio recorder and notes were taken. Analyzing the transcripts helped in obtaining a detailed viewpoint of non-participants such as power relationships, public administration system, political parties and cultural values, and other pertinent factors. A total of thirty non-participants, interviewed during this study. The number of interviewees for each area was determined by the population and importance of tourism in that area. Consequently, interviews undertook in Ulu Chuchoh ( $n=13)$, followed by Bukit Bangkong $(\mathrm{n}=10)$ and finally smallest area Ulu Teris $(\mathrm{n}=7)$.

Thematic analysis engaged in data analysis, according to Bryman (2008) Thematic analysis help the researcher to construct the index of central themes and accordingly sub-themes to place every detail of transcripts in its related cell. A modified table designed in this study. On the right side a column of main questions including the subs and respective answers from transcript on the right.

\section{Non-participants and Discussion}

Six main questions in interview sessions used to investigate the non-participants' influencing factors. Further questions were asked in the shadow of the main questions. In the same way, respondents mentioned ideas about 
key features of their own situation during the interview sessions. The indicators were selected with the aim of covering the main aspects of the study including; economic, social, cultural and religious.

\subsection{Religious Concerns}

According to the resident's profile, all Banghuris occupants were Muslim and mostly sensibilities about Islamic concerns and rules. The question of "Does Homestay Program impacts on your traditions and culture?" was engaged to investigate the religious concerns among non-participants. Although there were residents that they didn't consider religious issues as a key challenge, there were non-participants who consider this phenomenon vitally. In this context, an Ulu Teris resident said that “... there are conflicts between non-Muslim tourists and our religious, my sister and my mother need to wear Hijab (compulsory Islamic dress code for Muslim women in front of strangers) if the tourists want to come to our home and stay with us. Coming tourist to our house means losing privacy". Furthermore, a 48 years old lady in Bukit Bangkong stated that her children may learn the wrong things from tourists. She said: "Although my children can learn good things from tourists, their non-Islamic cloths would affect on our children; especially when they can stay in our home". On the other hand, some residents noted there is no preference for Muslim tourists and religious is not affecting their decisions in joining the Homestay program.

\subsection{Envious Sensitivities}

Exploring envious sensitivity in Banghuris proves the existence of jealousy sensitivities among non-participants. Confidence between couples and envious sensitivities between three villages in Banghuris (conflicts in fair distribution of tourism benefits in Bukit Bangkon, Ulu Chuchoh and Ulu Teris) explored for understanding jealousy among non-participants.

In the context of confidence between couples, it may be said that there were some worries. The evidences indicate that there were respondents who feel jealous about their husbands' relationships and worry about losing the control over them. A respondent from Ulu Chuchoh in answering to the question of "Do you prefer single or married tourists? Is gender important for you or not, if you wanted to join homestay program?" stated: "I don't like accepting young girls while my husband is in the home" further she explained that "I prefer families, followed by single males and single women".

There was another sense of jealousy regarding place of residency. As mentioned previously, Banghuris contains three main areas. Considering Ulu Chuchoh plays central role in running Homestay with a total of 40 Homestay participants out of 80 , some non-participants in Ulu Teris and Bukit Bangkong perceive that Ulu Chuchoh residents have a better opportunity in joining Homestay. In this context, a respondent stated that “...I believe current chairman is a compassionate man, even if you are not a Homestay participant and face a problem he tries to solve your problem. But everybody knows that Homestay belongs to Ulu Chuchoh and Ulu Teris has little portion in decisions regarding the Homestay program. Homestay program belongs to all Banghuris people, but the benefits mostly go to Ulu Chuchoh..."

\subsection{Time and Capital limitation}

In addition to the religious concerns noted in an earlier section, time and capital limitation was another affecting factor among Banghuris non-participants. In this context, time limitation was the most common problem among full-time employee couples. It may be said, non-participants with full time jobs has less interest in joining the Homestay program due to time limitations.

On the other hand, the study finds that there are some respondents, who have enough time to receive tourists under the authority of Homestay program, but capital limitation is their critical issue in joining Homestay. In other words, insufficient capital to construct and facilitate even one room for tourists was their main obstacle for this group of non-participants. Further interview with the Homestay manager approved that new Homestay participants don't receive any financial support or loans by Ministry of Tourism, while their houses should have the minimum standard defined by the Ministry of Tourism to join the Homestay program. However, it should be kept in mind that those non-participants affected by capital limitations, agreed they are appealed to join Homestay if they could receive financial support.

\subsection{Education}

It is believed that higher educated residents have a more positive perception toward tourism development and as education level increases, the awareness of environmental, economic and cultural impacts of tourism will raise as well. In this study educated non-participants were studied to understand their willingness to participate. The results reveal that this group of non-participants has a better understanding and awareness of tourism development. In this context, a respondent explained the importance of tourism for Malaysian economic growth 
and the other emphasized the key role of tourism in remote area development and rural-urban migration prevention. Although educated non-participants were highly interested to join the Homestay program, time limitation was the main barrier for them. All educated non-participants who interviewed were engaged in full-time jobs and no more time to join Homestay.

\subsection{Communication Barriers}

Lack of English language skill was another preventing factor for non-participants. Although the majority of interviewees could communicate in English, there were some respondents who couldn't, mostly older residents. In this regard, a respondent noted "...My children who can speak English already married and cannot help me in communicating tourists and my younger son goes school...". But she confessed that she can receive local tourists or tourists from Indonesia due to language similarities. (Considering Malaysia and Indonesia have 97\% similar language and both).

\subsection{Relation with Current Participants}

An immediate observable factor regarding non-participants was their relations with other Homestay participants and the importance of receiving negative signals from current participants. Transcript analysis shows that current participants in a Homestay program play a vital role in motivating or uninspiring non-participants in joining Homestay. In this sense, relation with current participants may be working as a boosting variable which intensify the effect of other factors such as communication barriers, time and capital limitation, religious and cultural concerns and envious sensitivities of non-participants decision. In this perspective, a respondent noted that “...Last time my sister received a European tourist which comes to breakfast table with improper clothes which is not good in our religious" which shows the effect of her sister on her perception toward tourism development, and the other noted "One of my friends which is a member of Homestay faced a problem with some tourists when they smoke cigarette in the house, while his daughter had Asthma illness" which shows the intensive effect of current participants on religious concerns and cultural differences.

\section{Conclusion}

Studying non-participants behavior towards tourism development in Community Based Tourism may be important as well as studying participants' behavior as they comprise most of the population in a community. Although the majority of the non-participants may feel the tangible and non-tangible benefits of tourism and agree to join Homestay, there are some people who find out joining Homestay harmful. Using the previous works indicators in understanding non-participants supporting behavior in this study reveal a new spectrum of influencing factors in the context of Community Based Tourism and specifically the Homestay program.

Obstacles to a wider participation of community may be solved thorough: allocating local or Indonesian visitors to those non-participants afraid of linguistic communications because of their cultural and linguistic similarities and moreover, finical supporting for those families facing monetary problems to facilitate and renew their house to receive tourists. In addition, according to Lisa Bond a practical example of Kaikoura whale watchin8ug New Zealand showed educating and informing people about the advantages of tourism development can reduce the effect of jealous sensitivities (Personal Communication, 2012, Dec 17). In the case of Banghuris Homestay, distributing tourism benefits in Ulu Teris and Bukit Bangkong equally to Ulu Chuchoh may moderate envious sensitivities among them.

To achieve a higher level of local participation in Community-Based Tourism a broad range of factors will need to be studied. For instance the effect of locals' financial literacy in the participatory process may be considered in a separate study and also the following questions need to be addressed: What special training or program could be enhanced to encourage non-participants to get involved Homestay program? How could reduce the negative perception of non-participants toward tourism development? How could reduce the effects of cultural differences with tourists? These questions demonstrate the necessity of further research and consideration of non-participants views in the planning process and managing CBT destinations.

\section{References}

Alonso, A. D., \& Liu, Y. (2012). Local community, volunteering and tourism development: The case of the Blackwood River Valley, Western Australia. Current Issues in Tourism, 1-16. http://dx.doi.org/10.1080/ 13683500.2011.644770

Bagul, P., \& Bahar, A. (2009). Success of Ecotourism Sites and Local Community Participation in Sabah. Victoria University of Wellington.

Brager, G., Specht, H., \& Torczyner, J. (1973). Community Organizing (p. 362). New York: Columbia University 
Press.

Bryman, A. (2008). Social research methods (3rd ed.). Oxford; New York: Oxford University Press.

Buono, F., Pediaditi, K., \& Carsjens, G. J. (2012). Local Community Participation in Italian National Parks Management: Theory versus Practice. Journal of Environmental Policy \& Planning, 14(2), 1-20. http://dx.doi.org/10.1080/1523908X.2012.683937

Daldeniz, B., \& Hampton, M. P. (2012). Dive Tourism and Local Communities: Active Participation or Subject to Impacts? Case Studies from Malaysia. International Journal of Tourism Research. http://dx.doi.org/10.1002/jtr.1897

Ebrahimi Meimand, S., \& Ismail, H. N. (2011). FEASIBILITY OF OPERATING HOMESTAY IN RURAL AREAS; A CASE STUDY OF MEIMAND, IRAN . In 3rd Sustainable Tourism Conference USM (p. 340). Penang: University Science Malaysia.

Flick, U. (2009). An Introduction to Qualitative Research (4th ed., p. 528). Los Angeles: Sage publications.

Garrod, B. (2003). Local Participation in the Planning and Management of Ecotourism: A Revised Model Approach. Journal of Ecotourism, 2(1), 33-53. http://dx.doi.org/10.1080/14724040308668132

Gillespie, A. (2000). THE BI-CULTURAL RELATIONSHIP WITH WHALES: BETWEEN PROGRESS, SUCCESS AND CONFLICT. lianz.waikato.ac.nz. Retrieved January 11, 2013, from http://lianz.waikato.ac.nz/PAPERS/al_gillespie/whales.pdf

Gunn, C. A., \& Var, C. A. G. T. (2002). Tourism Planning: Basics, Concepts, Cases (4th ed., p. 442). London: Routledge.

Gursoy, D., Jurowski, C., \& Uysal, M. (2002). Resident attitudes A Structural Modeling Approach. Annals of Tourism Research, 29(1), 79-105. http://dx.doi.org/10.1016/S0160-7383(01)00028-7

Hamzah, A. (1997). The evolution of small-scale tourism in Malaysia: Problems, opportunities and implications for sustainability. Tourism and Sustainability: Principles and Practices, 199-217.

Ibrahim, Y., \& Rashid, A. (2010). Homestay Program and Rural Community Development in Malaysia. Journal of Ritsumeikan Social Sciences and Humanities, 1(2), 7-24.

Inskeep, E. (1991). Tourism planning: An integrated and sustainable development approach (1st ed., p. 508). New York: Van Nostrand Reinhold.

Jafari, J. (1981). Limit to Tourism Development: An AIEST Conference Report. Journal of Travel Research, 19(3), 25-26. http://dx.doi.org/10.1177/004728758101900305

Kapoor, I. (2001). Towards participatory environmental management? Journal of Environmental Management, 63(3), 269-279. http://dx.doi.org/10.1006/jema.2001.0478

Kayat, K. (2002). Exploring factors influencing individual participation in community - based tourism: The case of Kampung relau homestay program, Malaysia. Asia Pacific Journal of Tourism Research, 7(2), 19-27.

Kibicho, W. (2008). Community-based Tourism: A Factor-Cluster Segmentation Approach. Journal of Sustainable Tourism, 16(2), 211-231. http://dx.doi.org/10.2167/jost623.0

Mair, H., \& Reid, D. G. (2007). Tourism and community development vs. tourism for community development: Conceptualizing planning as power, knowledge, and control. Leisure/Loisir, 31(2), 403-425. http://dx.doi.org/10.1080/14927713.2007.9651389

Meimand, S. (2013). Expectation and Experience Gap for Japanese Travelers Visiting Malaysian Homestay, Utilizing Holiday Satisfaction Model. Indian Journal of Science.

Mowforth, M. (2008). Tourism and sustainability: Development, globalization and new tourism in the third world (2nd ed., p. 424). London: Routledge.

Rosenow, J. E., \& Pulsipher, G. L. (1979). Tourism, the good, the bad, and the ugly (p. 264). Century Three Press.

Shani, A., \& Pizam, A. (2012). Handbook of Tourism and Quality-of-Life Research. In M. Uysal, R. Perdue, \& M. J. Sirgy (Eds.), Handbook of Tourism and Quality-of-Life Research (pp. 547-564). Dordrecht: Springer Netherlands. http://dx.doi.org/10.1007/978-94-007-2288-0

Shirlow, P., \& Murtagh, B. (2004). Capacity-building, representation and intracommunity conflict. Urban Studies. 
Simpson, M. C. (2008). Community Benefit Tourism Initiatives-A conceptual oxymoron? Tourism Management, 29(1), 1-18. http://dx.doi.org/10.1016/j.tourman.2007.06.005

Skeffington, A. (1969). People and planning. People and planning: report of the Committee on public participation in planning (p. 71). Scotland.

Stone, L. S., \& Stone, T. M. (2011). Community-based tourism enterprises: Challenges and prospects for community participation; Khama Rhino Sanctuary Trust, Botswana. Journal of Sustainable Tourism, 19(1), 97-114. http://dx.doi.org/10.1080/09669582.2010.508527

Stronza, A., \& Gordillo, J. (2008). Community views of ecotourism. Annals of Tourism Research, 35(2), 448-468. http://dx.doi.org/10.1016/j.annals.2008.01.002

Tosun, C. (2000). Limits to community participation in the tourism development process in developing countries. Tourism Management, 21(6), 613-633. http://dx.doi.org/10.1016/S0261-5177(00)00009-1

Yahya, F., And, A. P., \& Sebastian, R. (2005). Tourism and the South Asia littoral: Voices from the Maldives. South Asia: Journal of South Asian Studies, 28(3), 457-480. http://dx.doi.org/10.1080/00856400500337818

Yen, N. T. K., \& Van Luong, P. (2008). Participatory village and commune development planning (VDP/CDP) and its contribution to local community development in Vietnam. Community Development Journal, 43(3), 329-340. http://dx.doi.org/10.1093/cdj/bsn018

\section{Copyrights}

Copyright for this article is retained by the author(s), with first publication rights granted to the journal.

This is an open-access article distributed under the terms and conditions of the Creative Commons Attribution license (http://creativecommons.org/licenses/by/3.0/). 